\title{
Facile Synthesis of trans-S-1-Propenyl-L-Cysteine Sulfoxide (Isoalliin) in Onions (Allium cepa)
}

\author{
Sangku Lee, ${ }^{*}$ Jae Nyoung Kim, ${ }^{\dagger}$ Dong-Ho Choung, and Hyeong Kyu Lee* \\ Immune Modulator Research Center, KRIBB, Daejeon 305-806, Korea \\ *E-mail: sangku@kribb.re.kr (S.L.),hykylee@kribb.re.kr (H.K.L.) \\ Department of Chemistry and Institute of Basic Science, Chonnam National University, Gwangju 500-757, Korea \\ Received October 12, 2010, Accepted November 2, 2010
}

Key Words: Natural product, Amino acid, Isoalliin, Sulfoxide, Onion

\begin{abstract}
Allium species such as onions (Allium cepa) and garlic (Allium sativum) contain a variety of sulfur compounds which exhibit significant biological activities including anticarcinogenic, ${ }^{1}$ antitumorigenic, ${ }^{2}$ antimutagenic, ${ }^{3}$ antimicrobial, ${ }^{4}$ immunomodulatory, ${ }^{2 \mathrm{a}}$ cardiovascular-protective, ${ }^{5}$ and antioxidant effects. ${ }^{6}$ Several S-alk(en)yl-L-cystein sulfoxides have been reported to be present in genus Allium in the form of nonprotein sulfur amino acids. ${ }^{7}$ Trans-S-1-propenyl-L-cystein sulfoxide (isoalliin, 1) has been isolated from onions, ${ }^{7 a, 8}$ and it has been shown to be the precursor of the lachrymatory properties of Allium cepa by the action of the enzyme alliinase on the conversion of odorless trans-S-1-propenyl-L-cystein sulfoxide into the corresponding volatile thiosulfinate. ${ }^{9}$

Quantification of S-alk(en)yl-L-cystein sulfoxides is an important issue in Allium research. The unusual amino acid transS-1-propenyl-L-cystein sulfoxide (1) is in demand in the field of Allium chemistry including metabolism and biological studies, ${ }^{9 a}$ and serves as a standard for determination of S-alk(en)yl-Lcystein sulfoxides. Herein, we describe the facile synthesis of trans-S-1-propenyl-L-cystein sulfoxide in three steps.
\end{abstract}

The synthesis of trans-S-1-propenyl-L-cystein sulfoxide (1) was reported by three research groups. Nishimura and co-workers ${ }^{10}$ performed the isomerization of a terminal triple bond (ethyl prop-2-ynyl sulfide) to ethyl prop-1-ynyl sulfide and the subsequent reductive coupling with alkyl chloride as key reaction steps. Parry and Sood ${ }^{11}$ reported the synthesis of compound 1 in five steps without presenting a detail experimental description. They also used the isomerization of a terminal triple bond (benzyl prop-2-ynyl sulfide) to benzyl prop-1-ynyl sulfide in the scheme of synthesis of $\mathbf{1}$. Namyslo and Stanitzek ${ }^{12}$ utilized palladium-catalyzed coupling of a thiol with alkenyl bromide and completed the synthesis of compound $\mathbf{1}$ in five steps.

Our synthesis started with the formation of vinylsulfide $\mathbf{3}$

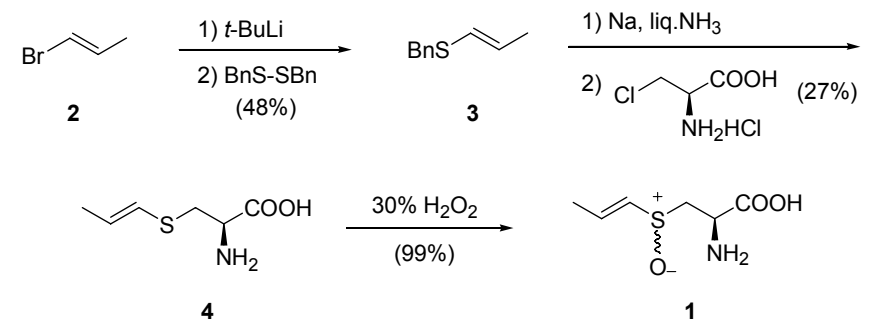

Scheme 1 from the commercially available (E)-1-bromo-1-propene (2), which by treatment with $t$-BuLi and the successive addition of dibenzyl disulfide afforded (E)-1-(benzylthio)-1-propen (3) (Scheme 1). ${ }^{13}$ The isomerically pure trans-(1-propen) compound 3 was obtained providing the characteristic large NMR coupling of the trans-olefinic protons $(J=15.0 \mathrm{~Hz})$. Reductive cleavage of a $\mathrm{C}-\mathrm{S}$ bond in compound $\mathbf{3}$ by $\mathrm{Na}$ in liquid $\mathrm{NH}_{3}$ followed by addition of 3-chloro-L-alanine hydrochloride gave trans-S-1-propenyl-L-cystein (4). ${ }^{14}$ Finally, the oxidation of sulfide 4 by aqueous hydrogen peroxide provided sulfoxide $\mathbf{1}$ in a quantitative yield. Compound $\mathbf{1}$ was obtained as a mixture of two diastereomers with a new formed sulfur chiral center. The structure of 1 was confirmed by a comparision with those in the literature. ${ }^{9 b, 12}$

In summary, a natural amino acid, trans-S-1-propenyl-Lcystein sulfoxide (1) was synthesized from (E)-1-bromo-1-propene in a concise way, via the sequential (i) the formation of vinylsulfide from lithiated propene and disulfide, (ii) reductive cleavage/alkylation of vinylsulfide, (iii) sulfide oxidation to sulfoxide. This compound is widely used as a reference for studies on Allium chemistry including biosynthesis of S-alkenylL-cystein sulfoxides, metabolism studies and biological investigations.

\section{Experimental}

Compound 3. To a solution of $t$-BuLi $(35.6 \mathrm{~mL}$ of a $1.7 \mathrm{M}$ solution in pentane, $60.5 \mathrm{mmol})$ in THF $(80 \mathrm{~mL})$ at $-78^{\circ} \mathrm{C}$ was added (E)-1-bromo-1-propene (2) (2.4 mL, $27.9 \mathrm{mmol})$. After $30 \mathrm{~min}$, dibenzyl disulfide $(6.56 \mathrm{~g}, 26.6 \mathrm{mmol})$ was added, and the reaction mixture was stirred at $0{ }^{\circ} \mathrm{C}$ for $1 \mathrm{~h}$. The reaction was quenched by addition of propylene oxide $(20 \mathrm{~mL})$ and the mixture was stirred for $30 \mathrm{~min}$. The reaction mixture was poured into a $15 \% \mathrm{NaOH}$ solution, extracted with hexane, washed with brine, dried over $\mathrm{MgSO}_{4}$, and concentrated in vacuo. The residue was purified by silica gel column chromatography (hexane as an eluent) to give $2.1 \mathrm{~g}(48 \%)$ of compound 3: ${ }^{1} \mathrm{H}$ $\operatorname{NMR}\left(300 \mathrm{MHz}, \mathrm{CDCl}_{3}\right) \delta$ 7.35-7.24 (m, 5H), 5.93 (br.dd, $J=$ $15.0,1.2 \mathrm{~Hz}, 1 \mathrm{H}), 5.71(\mathrm{dq}, J=15.0,6.9 \mathrm{~Hz}, 1 \mathrm{H}), 3.85(\mathrm{~s}, 2 \mathrm{H})$, $1.73(\mathrm{dd}, J=6.9,1.2 \mathrm{~Hz}, 3 \mathrm{H}) ;{ }^{13} \mathrm{C}$ NMR $\left(75 \mathrm{MHz}, \mathrm{CDCl}_{3}\right) \delta$ 137.8, 128.7, 128.4, 127.1, 126.9, 122.8, 37.5, 18.4; HRMS (EI) $m / z 164.0658$ [(M)+, calcd for $\left.\mathrm{C}_{10} \mathrm{H}_{12} \mathrm{~S} 164.0660\right]$.

Compound 4. Ammonia was condensed into a two-necked flask fitted with a dry ice-isopropyl alcohol condenser, which 
contained a solution of compound $3(2.0 \mathrm{~g}, 12.2 \mathrm{mmol})$ in ethyl ether $(4 \mathrm{~mL})$. The mixture was cooled to $-42{ }^{\circ} \mathrm{C}$ in a dry ice$\mathrm{CH}_{3} \mathrm{CN}$ bath and small pieces of sodium $(0.82 \mathrm{~g}, 35.6 \mathrm{mmol})$ were added until the blue color was persisted for $20 \mathrm{~min}$. Solid ammonium chloride was added to destroy the excess of sodium until the blue color disappeared. The ammonia was evaporated by a stream of argon, and the residue was dissolved in THF and cooled to $0{ }^{\circ} \mathrm{C}$. 3-Chloro-L-alanine hydrochloride (1.9 g, 12.0 mmol) was added, and the reaction mixture was stirred for $18 \mathrm{~h}$ at room temperature and poured into water. The mixture was adjusted to be $\mathrm{pH} 5$ - 6 using acetic acid, added to strongly acidic Amberlite and sirred for $10 \mathrm{~min}$. The ion exchanger was filtered by washing with water and $\mathrm{MeOH}$. The filtered ion exchanger was washed with $4 \mathrm{~N}-\mathrm{NH}_{4} \mathrm{OH}$ solution and the collected solution was concentrated in vacuo to yield $0.53 \mathrm{~g}(27 \%)$ of compound 4: ${ }^{1} \mathrm{H}$ NMR $\left(300 \mathrm{MHz}, \mathrm{D}_{2} \mathrm{O}\right) \delta 5.91-5.83(\mathrm{~m}, 2 \mathrm{H}), 3.82$ (m, 1H), 3.17 (dd, $J=14.7,3.6 \mathrm{~Hz}, 1 \mathrm{H}), 2.99$ (dd, $J=14.7,8.1$ $\mathrm{Hz}, 1 \mathrm{H}), 1.67(\mathrm{~d}, J=4.2 \mathrm{~Hz}, 3 \mathrm{H}) ;{ }^{13} \mathrm{C} \mathrm{NMR}\left(75 \mathrm{MHz}, \mathrm{D}_{2} \mathrm{O}\right) \delta$ $172.1,131.8,120.1,53.9,33.2,17.6$

Compound 1 (isoalliin). To a solution of compound $4(0.4 \mathrm{~g}$, $2.5 \mathrm{mmol})$ in $\mathrm{H}_{2} \mathrm{O}(35 \mathrm{~mL})$ at $0{ }^{\circ} \mathrm{C}$ was added $30 \% \mathrm{H}_{2} \mathrm{O}_{2}(0.29$ $\mathrm{mL}, 2.6 \mathrm{mmol})$. The mixture was stirred at room temperature for $16 \mathrm{~h}$ and concentrated in vacuo to give $0.43 \mathrm{~g}(99 \%)$ of compound 1: ${ }^{1} \mathrm{H}$ NMR $\left(300 \mathrm{MHz}, \mathrm{D}_{2} \mathrm{O}\right) \delta 6.69-6.54(\mathrm{~m}, 2 \mathrm{H})$, 6.47-6.39 (m, 2H), 4.11-4.01 (m, 2H), 3.57-3.15 (m, 4H), 1.91 $(\mathrm{d}, J=6.9 \mathrm{~Hz}, 3 \mathrm{H}), 1.87(\mathrm{~d}, J=6.9 \mathrm{~Hz}, 3 \mathrm{H}) ;{ }^{13} \mathrm{C} \mathrm{NMR}(75 \mathrm{MHz}$, $\left.\mathrm{D}_{2} \mathrm{O}\right) \delta 171.6,171.5,143.6,142.8,130.4,129.1,52.5,51.1$, $50.5,49.9,17.4,17.3$.

Acknowledgments. This research was supported by a grant from KRIBB Research Initiative Program.

\section{References}

1. (a) Lau, B. H. S.; Tadi, P. P.; Tosk, J. M. Nutr. Res. 1990, $10,937$. (b) Singh, S. V.; Pan, S. S.; Srivastava, S. K.; Xia, H.; Hu, X.; Zaren, H. A.; Orchard, J. L. Biochem. Biophys. Res. Commun. 1998, $244,917$.

2. (a) Kyo, E.; Uda, N.; Suzuki, A.; Kakimoto, M.; Ushujima, M.; Kasuga, S.; Itakura, Y. Phytomedicine 1998, 5, 259. (b) Siegers, C.-P.; Robke, A.; Pentz, R. Phytomedicine 1999, 6, 13.

3. Ishikawa, K.; Naganawa, R.; Yoshida, H.; Iwata, N.; Fukuda, H.; Fujino, T.; Suzuki, A. Biosci. Biotechnol. Biochem. 1996, 60, 2086.

4. Weber, N. D.; Anderson, D. O.; North, J. A.; Murray, B. K.; Lawson, L. D.; Hughes, B. G. Planta Med. 1992, 58, 417.

5. (a) Mirhadi, S. A.; Singh, S. Ind. J. Exp. Biol. 1991, 29, 162. (b) Morimitsu, Y.; Morioka, Y.; Kawakishi, S. J. Agric. Food Chem. 1992, 40, 368

6. (a) Prasad, K.; Laxdal, V. A.; Yu, M.; Raney, B. L. Mol. Cell. Biochem. 1995, 148, 183. (b) Yin, M.-C.; Cheng, W.-S. J. Agric. Food Chem. 1998, 46, 4097.

7. (a) Spare, G.; Virtanen, I. Acta Chem. Scand. 1963, 17, 641. (b) Stoll, A.; Seebeck, E. J. Experientia 1947, 3, 114. (c) Virtanen, I.; Matikkala, J. Acta Chem. Scand. 1959, 13, 1898. (d) Thomas, J.; Parkin, L. J. Agric. Food Chem. 1994, 42, 1632.

8. (a) Carson, J. F.; Lundin, R. E.; Lukes, T. M. J. Org. Chem. 1966, 31, 1634. (b) Krest, I.; Glodek, J.; Keusgen, M. J. Agric. Food Chem. 2000, 48, 3753.

9. (a) Block, E. Angew. Chem., Int. Ed. Engl. 1992, 31, 1135. (b) Breu, W. Phytomedicine 1996, 3, 293.

10. Nishimura, H.; Mizuguchi, A.; Mizutani, J. Tetrahedron Lett. 1975, 3201.

11. Parry, R. J.; Sood, G. R. J. Am. Chem. Soc. 1989, 111, 4514

12. Namyslo, J. C.; Stanitzek, C. Synthesis 2006, 3367.

13. Wu, Z.; Nguyen, S. T.; Grubbs, R. H.; Ziller, J. W. J. Am. Chem. Soc. 1995, 117, 5503.

14. Ford, P. W.; Narbut, M. R.; Belli, J.; Davidson, B. S. J. Org. Chem. 1994, 59, 5955. 